\title{
Cornsilk Fly (suggested common name), Euxesta stigmatias Loew (Insecta: Diptera: Otitidae) ${ }^{1}$
}

Gregg S. Nuessly and John L. Capinera²

\section{Introduction}

The 'cornsilk fly,' Euxesta stigmatias Loew, is an attractive, dark metallic green fly with distinctive wing patterns and wing flapping behavior commonly found throughout southern Florida agricultural communities. Its normally saprophytic life style belies its destructive nature when it comes to its preference for sweet corn ears. Entire fields may have to be passed up for harvest if they went untreated for this destructive pest or if individual treatments were missed due to weather, time or other constraints.

\section{Distribution}

Euxesta stigmatias is found in tropical and subtropical areas of the western hemisphere. It occurs throughout the Caribbean Islands, Mexico, Central and South America south to Bolivia and Paraguay, and in Florida. Historically it has been a pest in the United States only in southernmost Florida, Puerto Rico, and the Virgin Islands. However, in recent years cornsilk fly has become a serious pest in south-central Florida, and there are sporadic reports of its occurrence from Georgia and Texas. The genus Euxesta is represented by 36 species in North
America north of Mexico and 69 species in the Americas south of the United States. At least five additional species are known as crop pests, including E. annonae F., E. eluta Loew, and E. major Wulp, E. mazorca Steyskal, and E. sororcula (Weidemann) (Branco et al. 1994, Evans \& Zambrano 1991, Frias 1981, Painter 1955, Steyskal 1968 \& 1974).

\section{Life Cycle and Description}

Adults can be found throughout the year in south-central through southern Florida. The adults are adept at finding both adult and larval food sources. $E$. stigmatias completes development in 24 to 27 days on sweet corn and adults in captivity live an average of 116 days when provided with food and water.

Therefore, many generations are possible each year. Tolerance to freezing conditions is unknown.

\section{Eggs}

Females cannot penetrate intact plant tissue with their ovipositor. In most cases they deposit eggs into damaged, cracked, or decomposing plant issue. In sweet corn, eggs are deposited principally at the tip of the ear, within the silk, at the point of emergence

1. This document is EENY-224, one of a series of Featured Creatures from the Entomology and Nematology Department, Florida Cooperative Extension Service, Institute of Food and Agricultural Sciences, University of Florida. Published: August 2001. Revised: July 2005. This document is also available on Featured Creatures Website at http://creatures.ifas.ufl.edu. Please visit the EDIS Website at http://edis.ifas.ufl.edu.

2. Gregg S. Nuessly, associate professor, and John L. Capinera, chairman/professor, Entomology and Nematology Department, Institute of Food and Agricultural Sciences, University of Florida, Belle Glade, FL and Gainesville, FL, respectively. 
from the ear. Eggs are less commonly deposited between the husk leaves and around feeding holes in the husk caused by larval fall armyworm, Spodoptera frugiperda, and corn earworm, Helicoverpa zea. Young ears are most preferred; decaying ears are avoided. In the absence of ears, E. annonae may deposit eggs at the base of leaves or in the tassel, but survival rates are much lower than when they are deposited in ears. Eggs measure about $0.85 \mathrm{~mm}$ in length and $0.16 \mathrm{~mm}$ in width. They are white in color and cylindrical in shape, with ends that taper to a broadly rounded point. Eggs are usually deposited in small groups of 10 to 25 upwards to 40. Many females may deposit eggs within individual ears resulting in hundreds of eggs in each ear. Duration of the egg stage is 36 to 96 hours.

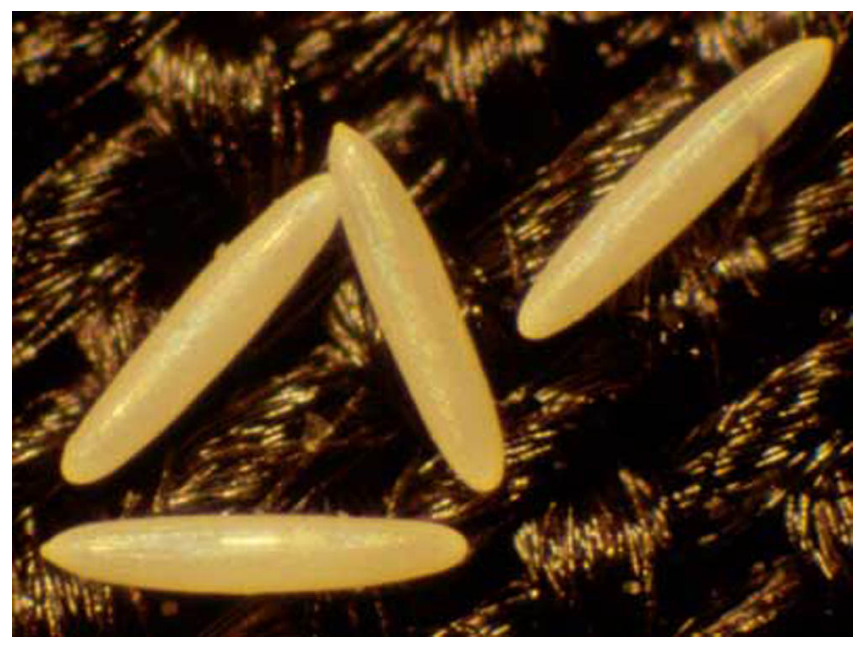

Figure 1. Eggs of the cornsilk fly, Euxesta stigmatias Loew. Credits: Matthew Hentz, USDA, ARS, Ft. Pierce, Florida

\section{Larvae}

Larvae are elongate and cylindrical in shape, with a blunt, broadly rounded posterior that tapers to a pointed head that is equipped with a pair of mouth hooks. Mature larvae measure about $5.4 \mathrm{~mm}$ in length. Larvae are whitish in color, and the ventral surface bears ridges and coarse spines. Larvae complete development in 10 to 16 days, passing through three instars.

\section{Pupae}

When the route out through the silk channel is not blocked by dried silk, the majority of larvae leave the ear to pupate within the top $2 \mathrm{~cm}$ of the soil

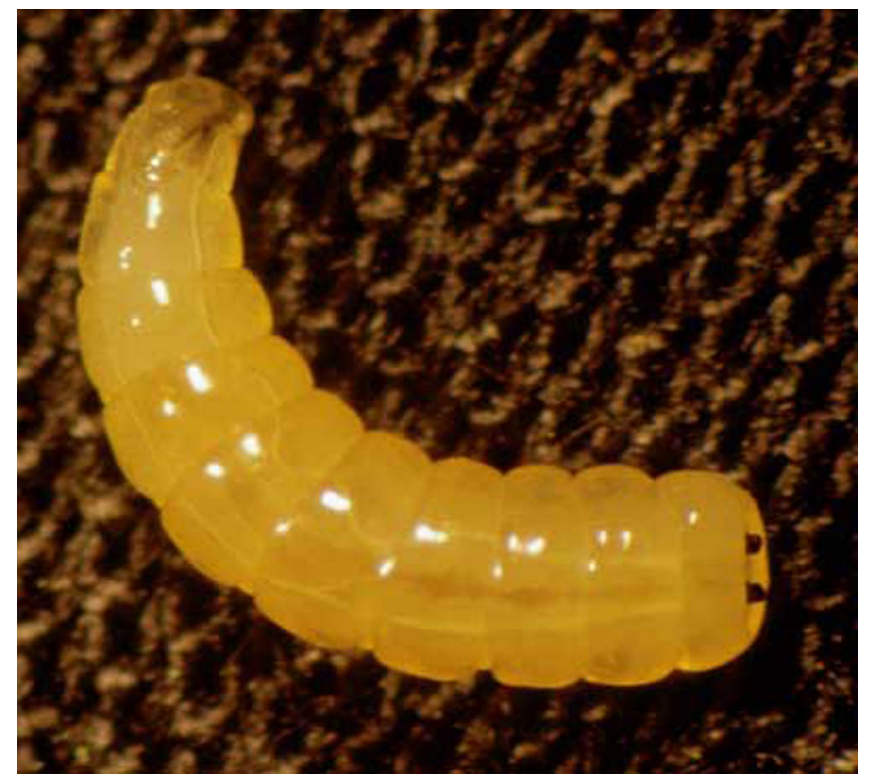

Figure 2. Last instar larvae of the cornsilk fly, Euxesta stigmatias Loew. Credits: Matthew Hentz, USDA, ARS, Ft. Pierce, Florida

surface. Larvae propel themselves from the corn ears by first grabbing the end of their abdomen with their mouth hooks and then quickly flexing their muscles to flip into the air to the soil. Some pupation occurs on the corn silks within or outside of the silk channel. The puparia are elongate and cylindrical, with the anterior end tapered to a blunt point and the body slightly flattened. They measure about $3.9 \mathrm{~mm}$ in length and $1.4 \mathrm{~mm}$ in width. Puparia are yellowish initially, becoming reddish brown after a few hours and then dark brown at maturity. E. stigmatias completes pupal development in eight to 11 days.

\section{Adults}

Adult flies are metallic green in color, with reddish brown eyes, and three complete, and a fourth incomplete, dark wing bands. Males measure about $3.8 \mathrm{~mm}$ in length, females about $4.2 \mathrm{~mm}$. The terminal end of the male abdomen is rounded, while that of the female ends in a trapezoid-shaped segment. Adults feed on pollen, nectar, plant sap and glandular exudates, and also drink from dew and rain droplets. The flies move their wings and walk in specific patterns in response to presence of other adults of their species, but also at other times when they are walking individually on plants. Adults are frequently observed sunning themselves early in the day, but quickly move into the shadows as sunlight 


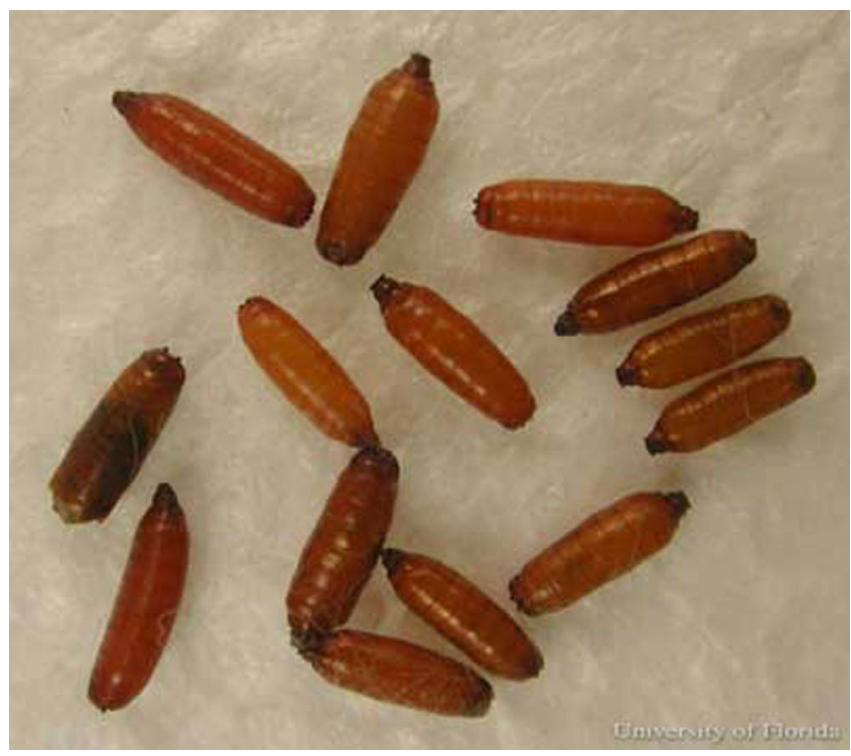

Figure 3. Pupae of the cornsilk fly, Euxesta stigmatias Loew. Credits: Gregg Nuessly, University of Florida

grows more intense. Mating occurs principally at dusk and dawn.

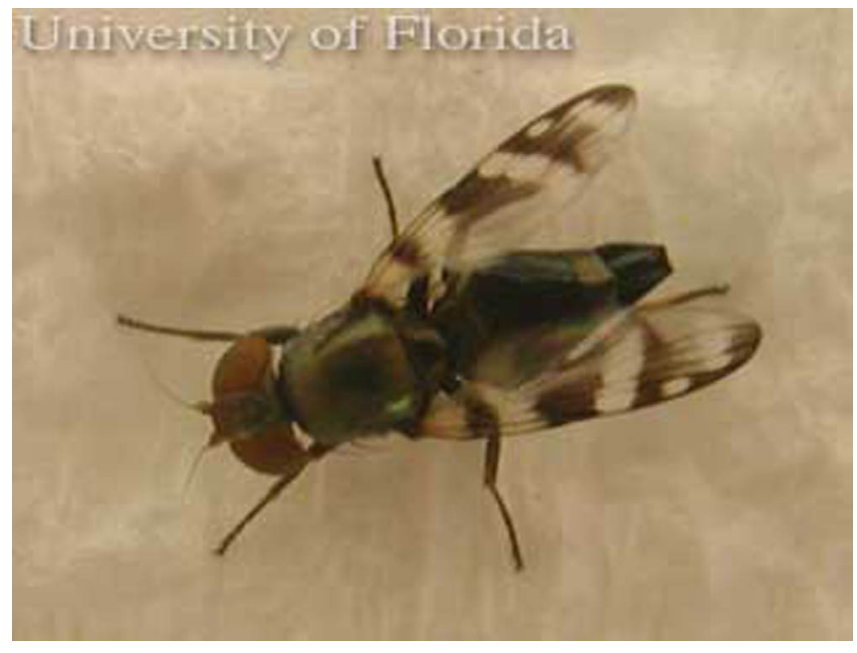

Figure 4. Adult female cornsilk fly, Euxesta stigmatias Loew. Credits: Gregg Nuessly, University of Florida

Biology is described by App (1938), Seal and Jansson $(1989,1993)$, Seal et al. $(1995,1996)$ and Hentz and Nuessly (2004).

\section{Host Plants}

Larvae and adults feed on a wide variety of plants, including such vegetables as sweet corn, potato, and tomato; such field crops as field corn, sorghum, and sugarcane; and such fruit crops as atemoya, banana, guava, and orange. However, sweet

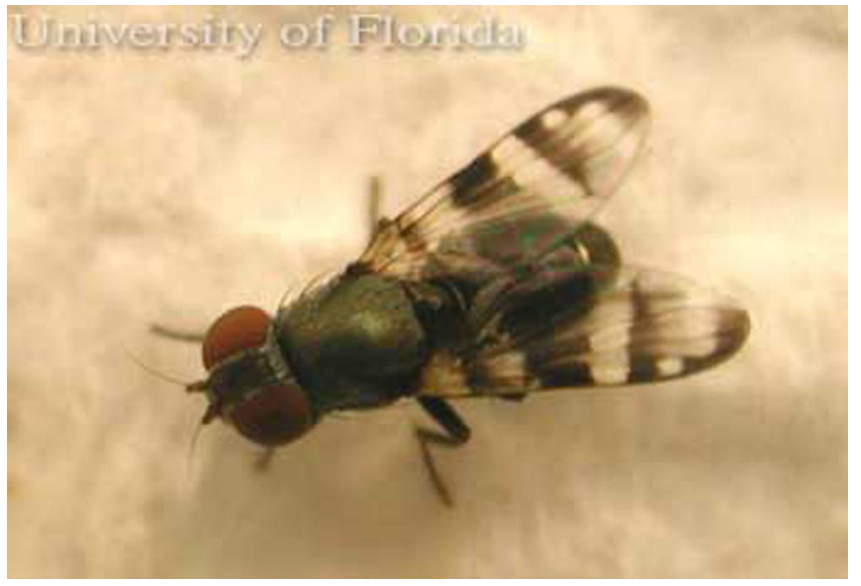

Figure 5. Adult male cornsilk fly, Euxesta stigmatias Loew. Credits: Gregg Nuessly, University of Florida

corn and field corn are highly preferred, and the only crops to be seriously damaged.

\section{Damage}

Damage is caused by the larval stage. Damage to corn silks results in poor kernel set. The silks turn a bronzed brown color along the path of larval feeding and under heavy infestation all of the silk will be clipped off within the silk channel. Larvae also feed on the tip of the cob resulting in blank tips. The principal injury is to the developing kernels on the ear, where they often hollow out the kernels. Larvae may be found feeding along the entire length of the ear. Yield reductions can reach $100 \%$, with peak levels of damage early in the season (Seal and Jansson 1989, Seal et al. 1996). Significant damage can occur even when insecticides have been applied. At-harvest ear infestations greater than $30 \%$ usually result in the field being rejected for fresh market.

Slight damage to tassels before they fully emerge and open from the whorl occasionally occurs due to feeding by other larval Euxesta sp.

\section{Natural Enemies}

Little is known concerning natural enemies. Eggs are consumed by earwigs (Dermaptera), mites (Acarina), and minute pirate bugs (Hemiptera: Anthocoridae). 


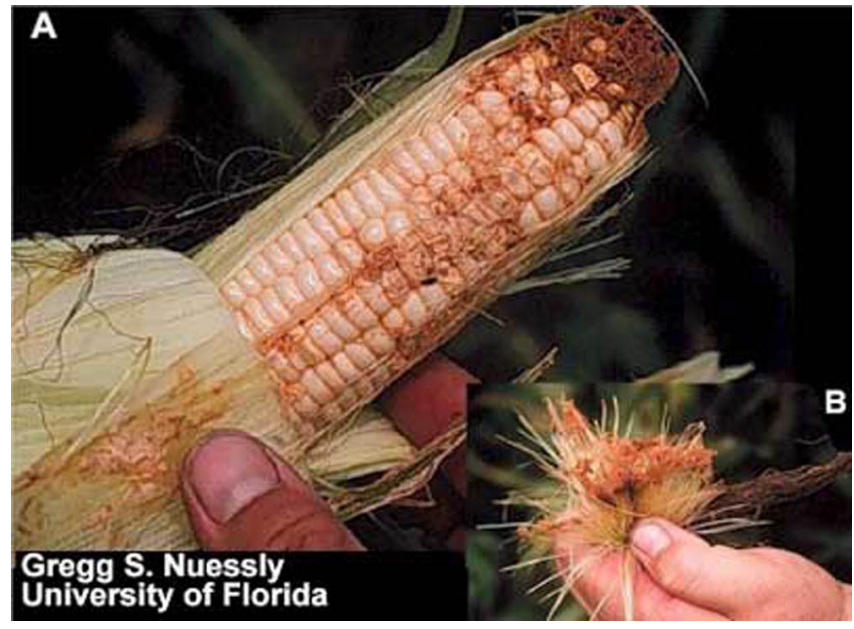

Figure 6. Damage by corn silk fly, Euxesta stigmatias Loew, larvae to sweet corn cv. 'Silver Queen' ear (A) and silk (B). Credits: Gregg Nuessly, University of Florida

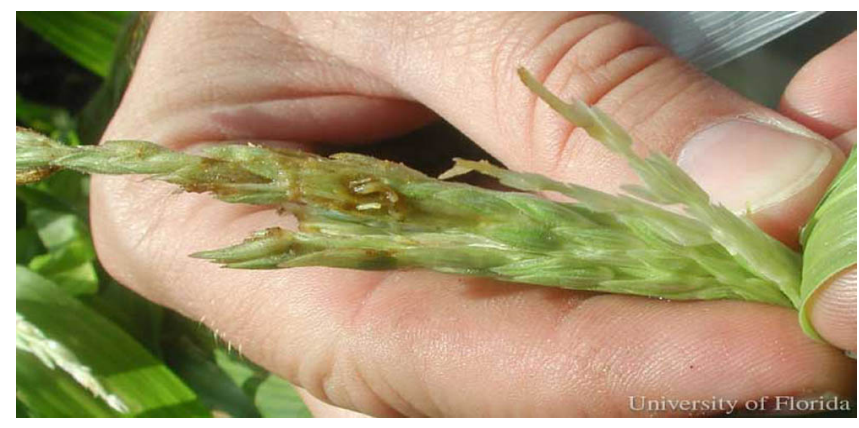

Figure 7. Damage by Euxesta sp. larvae to sweet corn tassel tissue within or just emerging from corn whorl. Credits: Gregg Nuessly, University of Florida

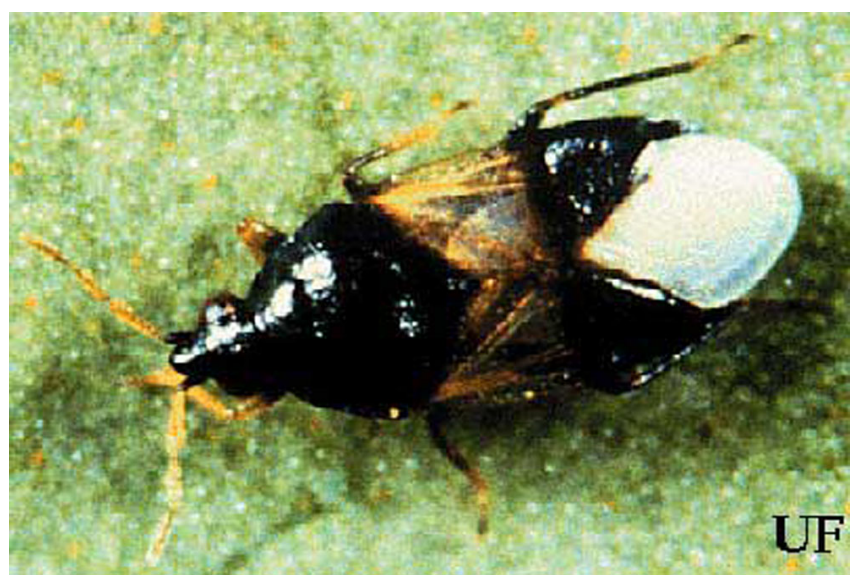

Figure 8. A minute pirate bug (Hemiptera: Anthocoridae); a predator of the cornsilk fly, Euxesta stigmatias Loew. Credits: University of Florida

\section{Management}

Eggs and larvae of this insect are protected within corn ears, and pupae are sheltered beneath the soil or within the ears. Therefore, conventional insecticidal control strategies target the adult stage. Sampling and management tactics are poorly developed. Sampling should commence before tasselling is initiated. Adults can be easily detected in the late afternoon and early evening when they rest on the plants and mate on the tassel. During silking, the silk channel should be checked for the presence of eggs. Timing and selection of insecticides is critical to reduce damage in presence of this pest. Infested fields should be treated with effective insecticides to reduce the population before silks emerge from the ears. These flies can quickly re-enter insecticide-treated fields from surrounding crop reservoirs.

Growers in affected areas rely on frequent insecticide applications to maintain a toxic residue on the rapidly developing corn silk. Organophosphate and pyrethroid insecticides are the most effective at killing corn silk flies (Nuessly and Hentz 2004). Residues of all but the organophosphate methyl parathion kill less than $40 \%$ of flies on plants 24 hours after treatment. The pyrethroid cyfluthrin produces debilitating sub-lethal effects on $70 \%$ of flies exposed to residues up to five days after treatment. Alternatives to insecticides are few at this time. Research has found that cultivars with high levels of maysin in cornsilk have some resistance to cornsilk fly (Scully et al. 2000).

In very small fields or homeowner situations, covering the ear beginning at initial silk emergence with a homemade mesh bag (e.g., bridal veil material, $20 \times 20$ to $32 \times 32 \mathrm{mesh}$ ) is an efficient method to greatly reduce egg deposition while still allowing for pollination.

Similar Euxesta species are found in maize and vegetables throughout North America, but they are not currently considered to be pests. E. annonae has been identified damaging emerging tassel tissue in sweet corn in southern Florida. There are several species of Euxesta in Florida. Therefore, unless you are familiar with the different species in your area, specimens should be properly identified to species by a reliable taxonomist as soon as they appear to determine whether they pose a threat to the corn crop. 
For more management information, see:

Insect Management Guide for Sweet Corn (http://edis.ifas.ufl.edu/IG158)

Insect Management Guide for Field Corn (http://edis.ifas.ufl.edu/IG060)

\section{Selected References}

App BA. 1938. Euxesta stigmatias Loew, an otitid fly infesting ear corn in Puerto Rico. Journal of Agriculture of the University of Puerto Rico 23:181-187.

Branco MC, Villas Boas GL, Reifschneider FJB, Cruz I. 1994. Evaluation of resistance to Helicoverpa zea (Lepidoptera: Noctuidae)(Boddie) and Euxesta sp. (Diptera: Otitidae) in lines of sweet corn. Anais da Sociedade Entomologica do Brasil 23: 137-140.

Capinera JL. Handbook of Vegetable Pests. Academic Press, San Diego. 729 pp.

Evans DC, Zambrano E. 1991. Insect damage in maize of highland Ecuador and its significance in small farm pest management. Tropical Pest Management 37: 409-414.

Frias D. 1981. Diferencias de microhabitats entre Euxesta eluta y Euxesta annonae (Diptera, Otitidae). Agricultura Tecnica (Chile) 41: 89-94.

Hentz MG, Nuessly GS. 2004. A technique for rearing the sweet corn pest, Euxesta stigmatias (Diptera: Otitidae) on a Helicoverpa diet. Journal of Entomological Science 39: 140-143.

Nuessly G., Pernezny K, Stansly P, Sprenkel R, Lentini R. (1999). Florida Corn Insect Identification Guide. UF/IFAS. http://fciig.ifas.ufl.edu/frcsilk.htm (27 July 2001).

Nuessly GS, Hentz MG. 2004. Contact and leaf residue activity of insecticides against the sweet corn pest Euxesta stigmatias Lowe (Diptera: Otitidae). Journal of Economic Entomology 97: 496-502.

Painter RH. 1955. Insects on corn and teosinte in Guatemala. Journal of Economic Entomology 48: 36-42.
Scully BT, Nuessly GS, Beiriger RL. 2000. Resistance in maize to Euxesta stigmatias Loew (Diptera: Otitidae). Journal of Entomological Science. 35: 432-443.

Seal DR, Jansson RK. 1989. Biology and management of corn-silk fly, Euxesta stigmatis Loew (Diptera: Otitidae), on sweet corn in southern Florida. Proceedings of the Florida State Horticultural Society 102:370- 373.

Seal DR, Jansson RK. 1993. Oviposition and development of Euxesta stigmatis (Diptera: Otitidae). Environmental Entomology 22:88-92.

Seal DR, Jansson RK, Bondari K. 1995. Bionomics of Euxesta stigmatis (Diptera: Otitidae) on sweet corn. Environmental Entomology 24:917-922.

Seal DR, Jansson RK, Bondari K. 1996. Abundance and reproduction of Euxesta stigmatis (Diptera: Otitidae) on sweet corn in different environmental conditions. Florida Entomologist 79:413-422.

Steyskal GC. 1968. Family Otitida (Ortalidae: including Pterocallidae, Ulidiidae), pp 54.1-54.31. In Vanzolini PE, Papavero N. [eds.], A Catalogue of the Diptera of the Americas South of the United States. Depto Zoologia, Secretaria de Agricultura, Sao Paulo, Brasil.

Steyskal GC. 1974. Euxesta mazorca, new species, associated with ears of maize in South America (Diptera, Otitidae). Proceedings of the Biological Society of Washington 87: 73-76.

Wilkerson JL, Webb SE, Capinera JL. (2005). Vegetable Pests I: Coleoptera - Diptera Hymenoptera. UF/IFAS CD-ROM. SW 180. 